\title{
Serotonin Receptor 3A Expression in Normal and Neoplastic B Cells
}

\author{
Andrea Rinaldi ${ }^{a}$ Anna Maria Chiaravalli ${ }^{b}$ Michael Mian ${ }^{a}$ Emanuele Zucca ${ }^{a}$ \\ Maria Grazia Tibiletti ${ }^{b}$ Carlo Capella ${ }^{b}$ Francesco Bertoni ${ }^{a}$ \\ a Laboratory of Experimental Oncology and Lymphoma Unit, Oncology Institute of Southern Switzerland (IOSI), \\ Bellinzona, Switzerland; ${ }^{\mathrm{b}}$ Anatomic Pathology Unit, University of Insubria, Ospedale di Circolo, Varese, Italy
}

\section{Key Words}

5-Hydroxytryptamine receptor $3 \mathrm{~A} \cdot$ Chromosome 11 . Lymphoma

\begin{abstract}
Chromosome 11q21-qter is a very gene-rich region and is often targeted by genomic aberrations in a variety of human cancers, including B cell lymphoid neoplasms. In order to identify genes which could be deregulated in diffuse large $B$ cell lymphomas (DLBCL), we analyzed the expression levels of genes mapped on chromosome 11q21-qter across a series of publicly available DLBCL expression data sets. We identified HTR3A, the gene coding for 5-hydroxytryptamine receptor $3 \mathrm{~A}$, as the most frequently differentially expressed. Since HTR3A expression had not been previously characterized in normal and neoplastic B cells, we evaluated its expression by real-time PCR and by immunohistochemistry. The gene is expressed by $B$ cells and it seems to be regulated during the mature Bcell differentiation, being overexpressed during the germinal center phase. Lymphomas derived from germinal center B cells maintain the expression, with the level of expression varying among different patients.
\end{abstract}

Copyright $\odot 2010$ S. Karger AG, Basel

\section{Introduction}

Chromosome 11q21-qter is a very gene-rich region and is often targeted by genomic aberrations in a variety of human cancers, including B cell lymphoid neoplasms. Gains of the chromosome 11q22-24 region have been reported in $15-20 \%$ of diffuse large B cell lymphomas (DLBCL) [1-4]. Moreover, the chromosome 11q21-qter region is also the target of translocations and deletions, especially in chronic lymphocytic leukemias and in mantle cell lymphomas (MCL), but also in DLBCL [5-14]. The gene coding for the ATM gene is the only gene on 11q2224 which has been clearly shown to be inactivated by genomic events and playing an active role in the pathogenesis of lymphoid tumors [15].

In order to identify genes which could be deregulated in DLBCL, we analyzed the expression levels of genes mapped on chromosome 11q21-qter across a series of publicly available DLBCL expression data sets [16-19].

Andrea Rinaldi and Anna Maria Chiaravalli equally contributed to this work.

\section{KARGER \\ Fax +41613061234 \\ E-Mail karger@karger.ch}

www.karger.com
(C) 2010 S. Karger AG, Basel

$1015-2008 / 10 / 0773-0129 \$ 26.00 / 0$

Accessible online at:

www.karger.com/pat
Dr. Francesco Bertoni

Laboratory of Experimental Oncology

Oncology Institute of Southern Switzerland (IOSI)

Via Vincenzo Vela 6, CH-6500 Bellinzona (Switzerland)

Tel. +41 918200 367, Fax +41 918200 397, E-Mail frbertoni@mac.com 
We identified HTR3A, the gene coding for 5-hydroxytryptamine receptor $3 \mathrm{~A}$, as the gene up- or downregulated in the highest number of samples of the data sets. Since HTR3A expression had not been previously characterized in normal and neoplastic B cells, we evaluated its expression by real-time PCR and by immunohistochemistry.

\section{Materials and Methods}

\section{Microarray Data Analysis}

CEL files, which contain all the probe cell intensities for all probe sets represented on the Affymetrix GeneChip microarrays (Affymetrix, Santa Clara, Calif., USA), were downloaded for 3 publicly available data sets [16-18]. Raw signal intensities were extracted using Affymetrix MAS 5.0 (Affymetrix). Already extracted but still unscaled and not normalized data were also downloaded for a fourth data set [19].

All the raw data were imported in GeneSpring 6.0 (Agilent, Palo Alto, Calif., USA). Since data were coming from different laboratories and produced on different generations of microarrays (Affymetrix Hu6800, HG-95Av1, HG-95v2, U133), 4 individual GeneSpring experiments were created. Chromosome 11q21-qter cytogenetic band-specific probe lists were built using the 12-2003 Affymetrix annotation files.

For each data set normalization, signal values below 0.01 were set to 0.01 . The percentile of all the measurements in each sample was calculated using all genes not marked absent and each gene measurement was divided by the 50th percentile. Then, each gene was divided by the median of its normalized measurements in all the data set samples; if the median of the normalized values was below 0.01 , then each measurement for that gene was divided by 0.01 . Genes were filtered for signal intensity and for up- or downregulation among the samples. Genes which did not present a signal intensity above 100 in at least $10 \%$ of the samples were discarded. Genes were ranked according to the number of samples in which their expression level was significantly up- or downregulated relative to the gene median in the data set, using a t testbased deviation from 1 with 0.2 as p value cutoff.

\section{Lymphoma Samples}

Lymph node samples were collected immersed in RNAlater solution (Ambion Inc., Austin, Tex., USA) and stored at $-80^{\circ} \mathrm{C}$ according to the manufacturers' guidelines. Approximately 2$\mathrm{mm}$ cubed tissue biopsies were homogenized in TRIzol (Invitrogen AG, Basel, Switzerland) using the TissueLyser (Qiagen AG, Hombrechtikon, Switzerland) and 3-mm tungsten carbide beads. RNA was extracted from 12 DLBCL, 16 follicular lymphomas (FL), 4 MCL, 8 DLBCL cell lines and 4 MCL cell lines. Cell lines were grown as described elsewhere [20,21]. All patients provided informed consent prior to tissue collection.

\section{Flow Cytometry and Cell Sorting}

Tonsils were obtained from routine tonsillectomies performed at the San Giovanni Hospital, Bellinzona, Switzerland. The specimens were kept on ice immediately after surgical removal, and all cell isolation steps were performed on ice. B cell subsets were isolated by magnetic cell separation using the MACS system (Miltenyi Biotech, Bergisch Gladbach, Germany) according to the CD19 marker expression. Further isolation was performed by sorting the CD19+ cells on a FACSVantage (Becton Dickinson). Centrocytes were identified as $\mathrm{CD} 38^{\text {high }} \mathrm{CD} 77_{-}$, centroblasts as $\mathrm{CD} 38^{\text {high }} \mathrm{CD} 77-$, naïve $\mathrm{B}$ cells as $\mathrm{CD} 38^{\text {low }} \mathrm{CD} 77-\mathrm{CD} 27-$, and memory B cells as CD38 ${ }^{\text {low }}$ CD77-CD27+.

\section{Real-Time Polymerase Chain Reaction}

RNA was extracted using Qiagen RNA easy kit. The concentration of total RNA was determined spectrophotometrically at $260 \mathrm{~nm}$ using the NanoDrop (NanoDrop Technologies, Wilmington, Del., USA) and both RNA quality and presence of contaminating genomic DNA were assessed with the Agilent Bioanalyzer 2100.

One microgram of total RNA was reverse-transcribed using the Superscript First-Strand Synthesis System for RT-PCR kit (Invitrogen, Karlsruhe, Germany) according to the manufacturer's instructions.

Real-Time PCR amplification was performed using TaqMan chemistry on an ABI Prism 7000 Sequence Detection System (Applied Biosystems, Foster City, Calif., USA). Primer and probe sets were obtained as Assays on Demand (Applied Biosystems): HS00168375 for HTR3A, HS99999903_m1 for $\beta$-actin. The standard curve method was used to quantify the results obtained by real-time PCR. All samples were analyzed in triplicate on 96-well plates in parallel with a series of 5 dilutions of standard cDNA of cell lines. The relative quantity of the specific mRNA for each sample was calculated based on mean cycle threshold values and with the corresponding standard curve. We used a correction for experimental variations by normalization to the average of the housekeeping gene $\beta$-actin.

\section{Immunohistochemistry}

The immunohistochemical expression of the receptor was investigated in 5 human non-neoplastic tonsils and lymph nodes and in a series of lymphomas, including 11 germinal center cell type DLBCL, 11 activated B cell type DLBCL, 11 (6 grade I, 3 grade II, and 2 grade III) FL and 5 MCL. Lymphomas were classified according to the criteria of the World Health Organization [22] and Hans et al. [23]. Formalin-fixed paraffin-embedded sections were mounted on poly-L-lysine-coated slides, dewaxed and hydrated through graded alcohols to water. After endogenous peroxidase activity inhibition with $3 \%$ hydrogen peroxide for $10 \mathrm{~min}$, proteolytic treatment was performed with $0.05 \%$ trypsin (T7409, Sigma) in $0.05 \mathrm{M}$ Tris buffer saline, $\mathrm{pH} 7.4$, for $20 \mathrm{~min}$ at $37^{\circ} \mathrm{C}$. Sections were later incubated overnight at $4^{\circ} \mathrm{C}$ with anti-5-hydroxytryptamine 3 receptor precursor polyclonal antibody (HTR3A, 1:250, Aviva System Biology, San Diego, Calif., USA) and immunostained with the avidin-biotin peroxidase complex method. Immunoreaction was developed with $0.03 \%$ 3,3'-diaminobenzidine tetrahydrochloride and nuclei were counterstained with hematoxylin.

Specificity controls consisted of substitution of the primary antibody with rabbit non-immune serum at the same dilution and use of control tissue with or without pertinent antigen and the absorption test with $10 \mathrm{nmol} / \mathrm{ml}$ of the specific antigen provided by Aviva System Biology (ID code: P01375). The antigen is a 50amino acid, N-terminal, peptide (from amino acid 12 to 61) from which the sequence used to generate the antibody was derived. 


\section{Results}

\section{Analysis of Public Data Sets}

We obtained the gene expression profiles of 3 previously published studies on DLBCL, on 3 different generations of Affymetrix arrays and including 58, 31 and 210 DLBCL cases [16-19]. We analyzed the 3 series individually, focusing on genes mapped on chromosome 11q21-qter. Table 1 shows the differentially expressed genes mapped on 11q21qter among the 3 analyzed DLBCL data sets. HTR3A, mapped at 11q23 and coding for the 5-hydroxytryptamine (serotonin) receptor $3 \mathrm{~A}$, appeared the most differentially expressed gene in all the 3 data sets.

\section{Analysis of HTR3A RNA Expression in Normal}

$B$ Cells

Since the gene expression profiles were not derived from pure B cell populations, we first assessed whether HTR3A gene can be expressed by normal B cells. We isolated normal tonsil B cell populations from 3 healthy individuals: naïve, centroblasts, centrocytes and memory B cells. Figure 1 shows that $H T R 3 A$ was expressed in all the populations, but its expression appeared higher in germinal center-derived cells. As an additional validation, we also analyzed HTR3A expression in a publicly available data set of normal B cells, which gave overlapping results [24].

\section{Analysis of HTR3A RNA Expression in B Cell}

Tumors

Once shown that HTR $3 A$ was differentially expressed in DLBCL microarray studies and that it can be expressed by normal B cells, we looked at its expression on a panel of B cell lymphoma clinical samples and cell lines.

As expected by the microarray data, the pattern of expression was not homogenous. Among clinical samples (fig. 1), all FL samples expressed HTR3A at levels similar or higher than normal B cells. In contrast, DLBCL samples as well as DLBCL cell lines showed a heterogeneous pattern of HTR $3 A$ expression with some samples expressing a low level of transcript (cycle threshold values higher than 30 cycles). Both MCL samples and cell lines had a level of HTR3A expression lower than the analyzed normal B cells, with 2 cell lines (REC and NCEB1) not expressing any transcript at all.

\section{HTR3A Protein Expression in Normal and Neoplastic Cells}

After having validated expression by PCR, we looked at HTR3A protein expression in normal and neoplastic B cells.
Table 1. Genes mapped on 11q21-qter and differentially expressed in publicly available data sets of diffuse large B cell lymphomas [16-19]

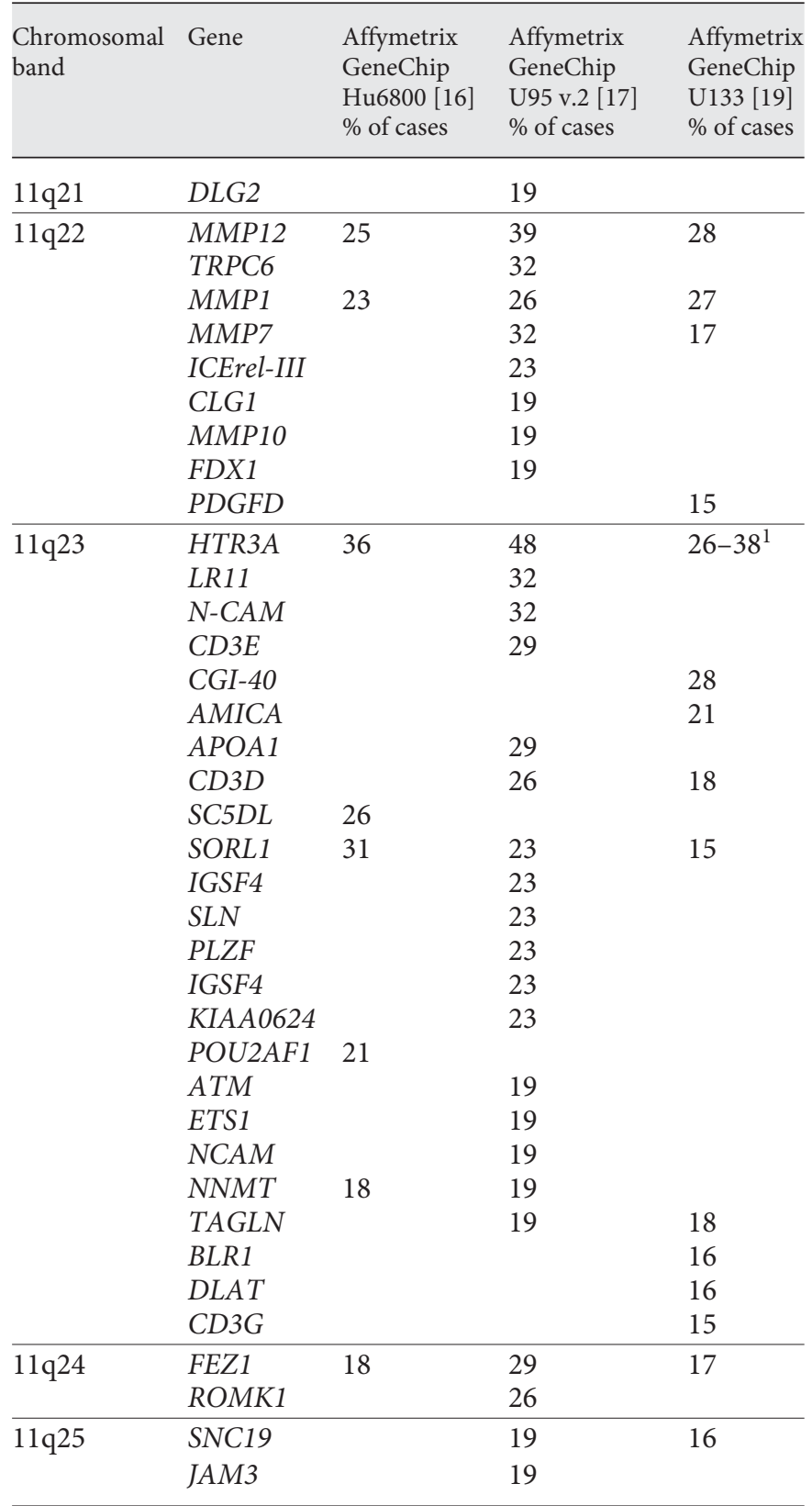

${ }^{1}$ More than 1 probe on the microarray.

In non-neoplastic tonsils and lymph nodes, HTR3A expression was prevalently observed in the germinal center of reactive follicles (fig. 2a, b). In particular, a weak to moderate immunoreactivity was detected in the cytoplasm of centrocytes and centroblasts. No membrane im-

Pathobiology 2010;77:129-135 
Fig. 1. RNA expression of HTR3A in normal tonsil B cell populations, lymphoma samples and lymphoma cell lines. $y$-axis: ratio of HTR $3 A / \beta$-actin. $\mathrm{NB}=$ Naïve $\mathrm{B}$ cells; $\mathrm{CB}=$ centroblasts; $\mathrm{CC}=$ centrocytes; $\mathrm{MB}=$ memory $\mathrm{B}$ cells.
Fig. 2. HTR3A staining on normal and lymphoma histological sections. Germinal center of tonsil (a) and lymph node (b) reactive follicle, showing cytoplasmic HTR3A immunoreactivity in centroblasts; consecutive sections of a DLBCL case showing HTR3A immunoreactivity (c) in the majority of CD20-positive (d) neoplastic $B$ cells. DAB-hematoxylin staining; original magnification: $\times 400$.
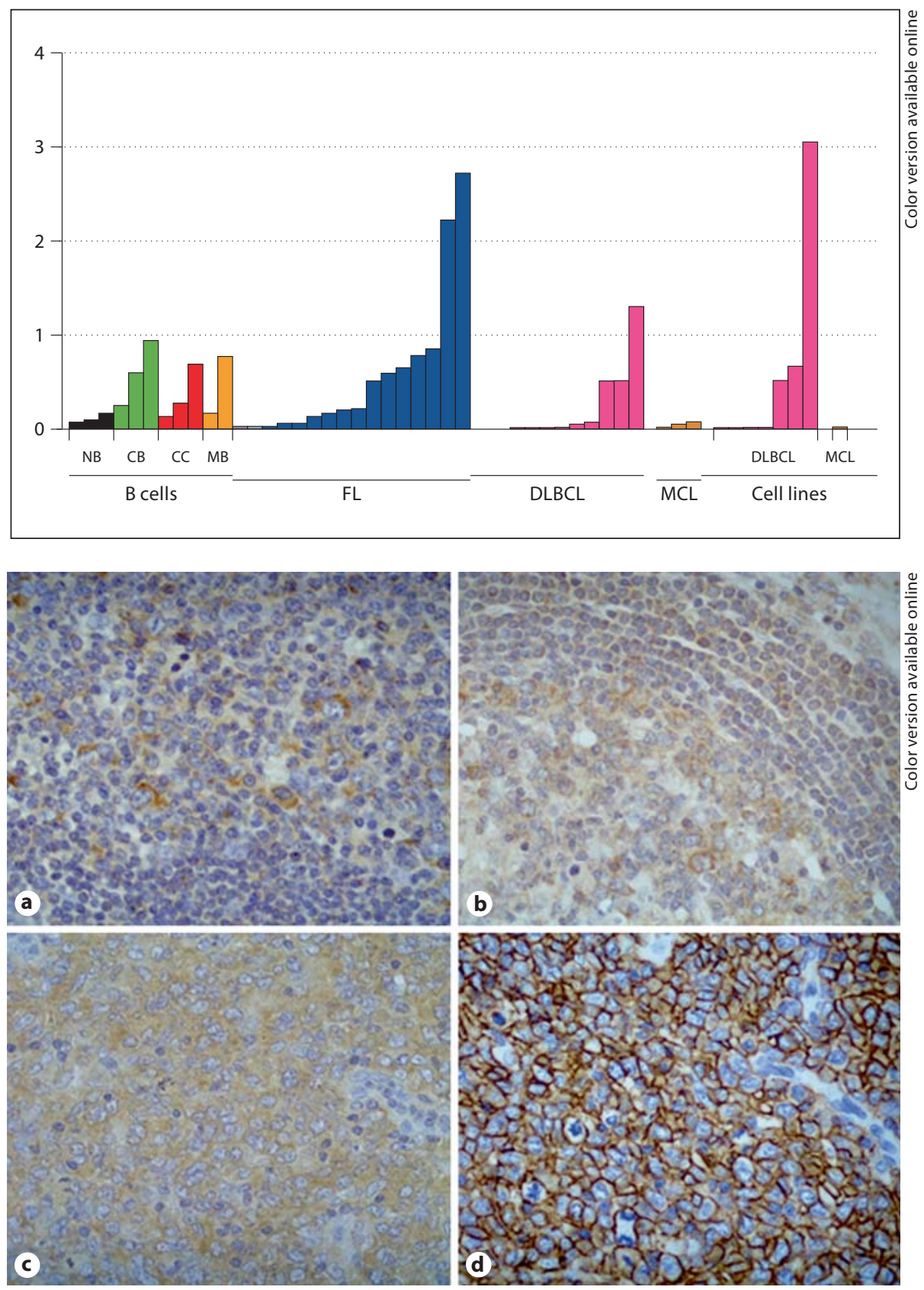

munoreactivity was observed. Plasma cells interspersed in lymphoid tissue were variably immunostained.

All FL and DLBCL showed immunohistochemical expression of the protein (table 2). The immunoreactivity varied from case to case both in intensity and in percentage of positive cells. In FL, HTR3A immunoreactivity was directly related to tumor grade: grade III FL showed a larger number of HTR3A immunoreactive cells, showing more intense positivity than grade II and grade I FL.
In FL, centroblasts displayed the strongest cytoplasmic immunoreaction (fig. 3a), sometimes marked close to cellular membrane, whereas a weak cytoplasmic immunoreactivity was present in small centrocytes. A similar pattern of expression was observed in both germinal center and activated B cell type DLBCL (fig. 3b, c). The protein was strongly expressed in the vast majority of neoplastic B cells (fig. 2c, d) but not in non-neoplastic (reactive) small lymphoid cells admixed with lymphomatous 
Fig. 3. Pattern of HTR3A immunostaining in FL, germinal center DLBCL, postgerminal center DLBCL and MCL. Grade III FL showing numerous HTR3A immunoreactive centroblasts (a); cytoplasmic HTR3A immunoreactivity in the majority of neoplastic B cells of a germinal center (b) and activated B cell type (c) DLBCL; absence of HTR3A immunoreactivity in a case of MCL. DAB-hematoxylin staining; original magnification: $\times 400$ in $\mathbf{a}, \mathbf{b}$, inset, $\mathbf{d}$; $\times 200$ in $\mathbf{c}$.
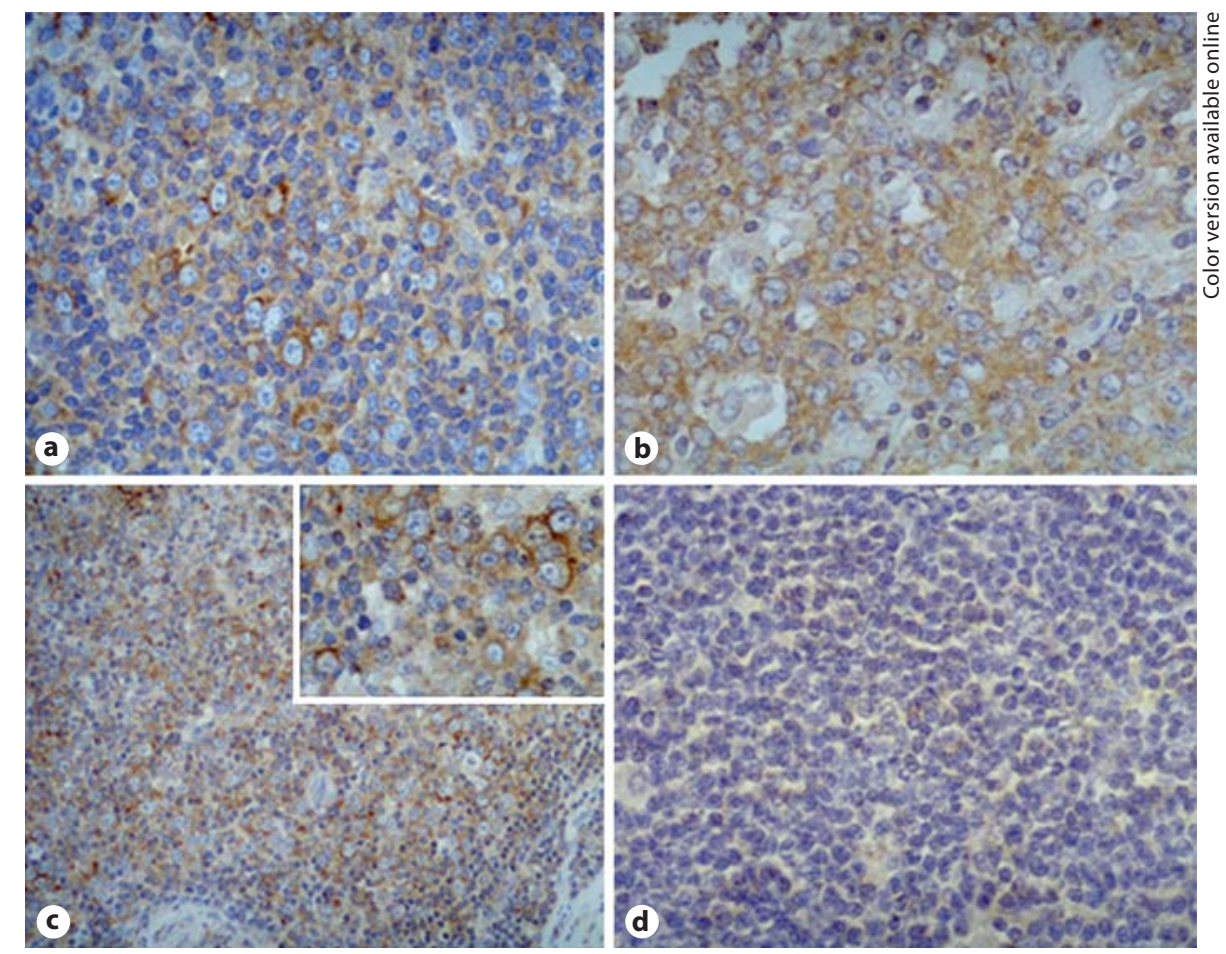

cells. No immunoreactivity was observed in MCL (fig. 3d).

Both after primary antibody omission and antigen absorption test all normal and neoplastic tissues did not show any immunoreactivity.

\section{Discussion}

By searching for genes mapped on the chromosome region 11q21-qter and differentially expressed in DLB$\mathrm{CL}$, we have identified the gene coding for the subunit A of the type 3 receptor for 5-hydroxytryptamine (HTR3A). Studying both RNA and protein level, we showed that HTR $3 A$ is expressed by normal B cells, and its expression is upregulated during the germinal center phase. FL and DLBCL, both germinal center-derived lymphomas, express HTR3A, while MCL express much lower HTRA levels. These findings help to clarify some previously reported data [25]. Two gene expression studies had identified HTR3A as one of the genes downregulated in MCL when compared with normal B cells [25] and, in normal $B$ cells, it had been reported among genes upregulated in germinal center B cells [24]. In both studies, HTR3A had not been specifically validated. Our data confirm these
Table 2. HTR3A immunohistochemical expression in different types of lymphoma

\begin{tabular}{llll}
\hline & $\begin{array}{l}\text { Positive cases/ } \\
\text { total cases }\end{array}$ & $\begin{array}{l}\text { Mean \% of } \\
\text { IR cells }\end{array}$ & $\begin{array}{l}\text { Staining } \\
\text { intensity }\end{array}$ \\
\hline Germinal center DLBCL & $11 / 11$ & $73(10-100)$ & $1+/ 3+$ \\
Activated B cell DLBCL & $11 / 11$ & $62(10-100)$ & $1+/ 3+$ \\
Follicular lymphoma & & & \\
$\quad$ Grade I & $6 / 6$ & $56(30-80)$ & $1+/ 3+$ \\
$\quad$ Grade II & $3 / 3$ & $76(70-80)$ & $1+/ 3+$ \\
$\quad$ Grade III & $2 / 2$ & $70(70)$ & $2+/ 3+$ \\
Mantle cell lymphoma & $0 / 5$ & 0 & \\
\hline
\end{tabular}

$\mathrm{IR}=\mathrm{Immunoreactive}$. Figures in parentheses indicate ranges.

reports at both the RNA and protein level, and identify HTR3A as a gene involved in B cell maturation.

Using an immunohistochemical technique, we observed a moderate to intense cytoplasmic staining among normal and neoplastic centrocytes, centroblasts and in neoplastic activated large B cells. All the immunoreactivity disappeared after the absorption of the primary antibody with the specific 5-HTR3A N-terminal peptide. In addition, the amino acid sequence of the peptide used to 
generate the antibody is common, in the Homo sapiens, only to the 5-HTR3A isoform $\alpha$ and $\beta$ precursor (NCBI BLAST protein alignment, BLASTP 2.2.18). Both these data confirm the specificity of our results about the immunohistochemical expression of 5-HTR3A.

5-HTR3A is a transmembrane protein composed of 5 subunits that surround a central ion-conducting pore. Each subunit is composed of an extracellular, a transmembrane and an intracellular domain [26]. We did not observe any clear-cut membrane stain; the immunoreactivity was prevalently localized in the cytoplasm. The antibody we used is directed against the extracellular, $\mathrm{N}$ terminal, domain that forms the ligand binding site [26]. This ligand binding site lies at the interface of 2 adjacent subunits. Thus, the antibody might recognize and label the unassembled subunits of the receptor rather than the functional form integrated into the cell membrane. Once the subunits are assembled the antibody might no longer have access to the antigenic sites or recognize the conformational structure of the assembled receptor. Taking all these observations into account our results provide an indication of the production and expression of 5-HTR3A in normal and neoplastic germinal center B cells.

HTR3A is a ligand-gated cation channel expressed in the central and peripheral nervous system, but also on other cells $[26,27]$. HTR 3 is the target of a widely used anti-emetic class of compounds [26]. In hematopoietic cells, monocytes and T cells are known to express HTR3A [28]. 5-HT affects the function of B and T cells [29-33]. The effect on lymphocytes is still not fully understood, but 5 -HT might contribute to lymphocyte activation [29, $30,32,33$. In pre-B-lymphocyte cell lines, physiological doses of 5-HT modulate cell activation regulating the potassium current via at least 2 receptors, 5-HTR1 and 5HTR3 [33]. However, 5-HT can also induce apoptosis, as it has been shown in Burkitt lymphoma cells, and this occurs not via binding to 5 -HTRs but via active transport in the neoplastic cells [34]. In our study, the germinal center centroblasts and the activated large B cells appeared as the neoplastic cells with the strongest immunoreactivity, a finding supporting the hypothesis that HTR3A might be involved in $B$ cell regulation. Indeed, the gene expression changes in B cells, which are moving from the naïve to the germinal center stage of development, and is characterized by a massive upregulation of genes involved in cell proliferation, but also by an upregulation of proapoptotic and downregulation of anti-apoptotic genes [24]. Regarding HTR3A expression in MCL, our data suggest that the previously reported downregulation [25] could reflect the normal low levels of expression of HTR3A in the cells of origin of MCL, more than a disease-related alteration.

In conclusion, we identified HTR $3 A$ as a gene involved in $B$ cell maturation. Further in vitro and in vivo studies will be necessary to understand its precise mechanism of action.

\section{Acknowledgments}

We thank Dr. D. Jarossay for assistance in cell sorting. The work was partially financially supported by grants of the San Salvatore foundation, Swiss Bridge Foundation, Oncosuisse OCS 01517-02-2004 and Fondazione per la Ricerca e la Cura sui Linfomi (Lugano, Switzerland).

\section{References}

1 Barth TF, Dohner H, Werner CA, Stilgenbauer S, Schlotter M, Pawlita M, Lichter P, Moller P, Bentz M: Characteristic pattern of chromosomal gains and losses in primary large B-cell lymphomas of the gastrointestinal tract. Blood 1998;91:4321-4330.

-2 Chan WY, Wong N, Chan AB, Chow JH, Lee JC: Consistent copy number gain in chromosome 12 in primary diffuse large cell lymphomas of the stomach. Am J Pathol 1998; 152:11-16.

-3 Rickert CH, Dockhorn-Dworniczak B, Simon R, Paulus W: Chromosomal imbalances in primary lymphomas of the central nervous system. Am J Pathol 1999;155:14451451.
-4 Starostik P, Patzner J, Greiner A, Schwarz S, Kalla J, Ott G, Muller-Hermelink HK: Gastric marginal zone B-cell lymphomas of malt type develop along 2 distinct pathogenetic pathways. Blood 2002;99:3-9.

5 Zhu Y, Monni O, Franssila K, Elonen E, Vilpo J, Joensuu H, Knuutila S: Deletions at $11 \mathrm{q} 23$ in different lymphoma subtypes. Haematologica 2000;85:908-912.

-6 Stilgenbauer S, Winkler D, Ott G, Schaffner C, Leupolt E, Bentz M, Moller P, Muller-Hermelink HK, James MR, Lichter P, Dohner H: Molecular characterization of $11 \mathrm{q}$ deletions points to a pathogenic role of the ATM gene in mantle cell lymphoma. Blood 1999;94: 3262-3264.
-7 Monni O, Zhu Y, Franssila K, Oinonen R, Hoglund P, Elonen E, Joensuu H, Knuutila S: Molecular characterization of deletion at 11q22.1-23.3 in mantle cell lymphoma. Br J Haematol 1999;104:665-671.

-8 Bertoni F, Conconi A, Cogliatti SB, Schmitz SF, Ghielmini M, Cerny T, Fey M, Pichert G, Bertolini F, Ponzoni M, Baldini L, Jones C, Auer R, Zucca E, Cavalli F, Cotter FE: Immunoglobulin heavy chain genes somatic hypermutations and chromosome 11q22-23 deletion in classic mantle cell lymphoma: a study of the Swiss group for clinical cancer research. Br J Haematol 2004;124:289-298.
Rinaldi/Chiaravalli/Mian/Zucca/ Tibiletti/Capella/Bertoni 
9 Kobayashi H, Espinosa R 3rd, Thirman MJ, Davis EM, Diaz MO, Le Beau MM, Rowley JD: Variability of 11q23 rearrangements in hematopoietic cell lines identified with fluorescence in situ hybridization. Blood 1993; 81:3027-3033.

10 Auer RL, Starczynski J, McElwaine S, Bertoni F, Newland AC, Fegan CD, Cotter FE: Identification of a potential role for POU2AF1 and BTG4 in the deletion of 11q23 in chronic lymphocytic leukemia. Genes Chromosomes Cancer 2005;43:1-10.

- 11 Kalla C, Scheuermann MO, Kube I, Schlotter M, Mertens D, Dohner H, Stilgenbauer S, Lichter P: Analysis of 11q22-q23 deletion target genes in B-cell chronic lymphocytic leukaemia: evidence for a pathogenic role of NPAT, CUL5, and PPP2R1B. Eur J Cancer 2007;43:1328-1335.

- 12 Akao Y, Seto M, Yamamoto K, Iida S, Nakazawa S, Inazawa J, Abe T, Takahashi T, Ueda $\mathrm{R}$ : The RCK gene associated with $\mathrm{t}(11 ; 14)$ translocation is distinct from the MLL/ALL1 gene with $\mathrm{t}(4 ; 11)$ and $\mathrm{t}(11 ; 19)$ translocations. Cancer Res 1992;52:6083-6087.

13 Rovigatti U, Watson DK, Yunis JJ: Amplification and rearrangement of Hu-ets-1 in leukemia and lymphoma with involvement of 11q23. Science 1986;232:398-400.

- 14 Zhao C, Inoue J, Imoto I, Otsuki T, Iida S, Ueda R, Inazawa J: POU2AF1, an amplification target at 11q23, promotes growth of multiple myeloma cells by directly regulating expression of a B-cell maturation factor, TNFRSF17. Oncogene 2008;27:63-75.

-15 Schaffner C, Stilgenbauer S, Rappold GA, Dohner H, Lichter P: Somatic ATM mutations indicate a pathogenic role of ATM in B-cell chronic lymphocytic leukemia. Blood 1999;94:748-753.

-16 Shipp MA, Ross KN, Tamayo P, Weng AP, Kutok JL, Aguiar RC, Gaasenbeek M, Angelo M, Reich M, Pinkus GS, Ray TS, Koval MA, Last KW, Norton A, Lister TA, Mesirov J, Neuberg DS, Lander ES, Aster JC, Golub TR: Diffuse large B-cell lymphoma outcome prediction by gene-expression profiling and supervised machine learning. Nat Med 2002; 8:68-74.

-17 Klein U, Tu Y, Stolovitzky GA, Mattioli M, Cattoretti G, Husson H, Freedman A, Inghirami G, Cro L, Baldini L, Neri A, Califano A, Dalla-Favera R: Gene expression profiling of B cell chronic lymphocytic leukemia reveals a homogeneous phenotype related to memory B cells. J Exp Med 2001;194:1625-1638.
8 Kuppers R, Klein U, Schwering I, Distler V, Brauninger A, Cattoretti G, Tu Y, Stolovitzky GA, Califano A, Hansmann ML, Dalla-Favera R: Identification of Hodgkin and ReedSternberg cell-specific genes by gene expression profiling. J Clin Invest 2003;111: 529-537.

19 Savage KJ, Monti S, Kutok JL, Cattoretti G, Neuberg D, De Leval L, Kurtin P, Dal Cin P, Ladd C, Feuerhake F, Aguiar RC, Li S, Salles G, Berger F, Jing W, Pinkus GS, Habermann T, Dalla-Favera R, Harris NL, Aster JC, Golub TR, Shipp MA: The molecular signature of mediastinal large B-cell lymphoma differs from that of other diffuse large B-cell lymphomas and shares features with classical Hodgkin's lymphoma. Blood 2003;102:38713879.

20 Lacrima K, Valentini A, Lambertini C, Taborelli M, Rinaldi A, Zucca E, Catapano C, Cavalli F, Gianella-Borradori A, Maccallum DE, Bertoni F: In vitro activity of cyclindependent kinase inhibitor CYC202 (Seliciclib, R-roscovitine) in mantle cell lymphomas. Ann Oncol 2005;16:1169-1176.

21 Lacrima K, Rinaldi A, Vignati S, Martin V, Tibiletti MG, Gaidano G, Catapano C, Bertoni $\mathrm{F}$ : Cyclin-dependent kinase inhibitor seliciclib shows in vitro activity in diffuse large B cell lymphomas. Leu Lymphoma 2007;48:158-167.

22 Jaffe ES, Harris NL, Stein H, Vardiman JW (eds): World Health Organization Classification of Tumours. Pathology and Genetics of Tumours of Haematopoietic and Lymphoid Tissues. Lyon, IARC Press, 2001.

23 Hans CP, Weisenburger DD, Greiner TC, Gascoyne RD, Delabie J, Ott G, Muller-Hermelink HK, Campo E, Braziel RM, Jaffe ES Pan Z, Farinha P, Smith LM, Falini B, Banham AH, Rosenwald A, Staudt LM, Connors JM, Armitage JO, Chan WC: Confirmation of the molecular classification of diffuse large B-cell lymphoma by immunohistochemistry using a tissue microarray. Blood 2004;103:275-282.
24 Klein U, Tu Y, Stolovitzky GA, Keller JL, Haddad J Jr, Miljkovic V, Cattoretti G, Califano A, Dalla-Favera R: Transcriptional analysis of the $\mathrm{B}$ cell germinal center reaction. Proc Natl Acad Sci USA 2003;100: 2639-2644.

25 Ek S, Hogerkorp CM, Dictor M, Ehinger M, Borrebaeck CA: Mantle cell lymphomas express a distinct genetic signature affecting lymphocyte trafficking and growth regulation as compared with subpopulations of normal human B cells. Cancer Res 2002;62: 4398-4405.

$>26$ Thompson AJ, Lummis SC: The 5-HT3 receptor as a therapeutic target. Expert Opin Ther Targets 2007;11:527-540.

$>27$ Farber L, Haus U, Spath M, Drechsler S: Physiology and pathophysiology of the 5HT3 receptor. Scand J Rheumatol Suppl 2004;119:2-8.

28 Fiebich BL, Akundi RS, Seidel M, Geyer V, Haus U, Muller W, Stratz T, Candelario-Jalil E: Expression of 5-HT3A receptors in cells of the immune system. Scand J Rheumatol Suppl 2004;119:9-11.

29 Vega Lde L, Munoz E, Calzado MA, Lieb K, Candelario-Jalil E, Gschaidmeir H, Farber L, Mueller W, Stratz T, Fiebich BL: The 5-HT3 receptor antagonist tropisetron inhibits $\mathrm{T}$ cell activation by targeting the calcineurin pathway. Biochem Pharmacol 2005;70:369380 .

30 Khan NA, Poisson JP: 5-HT3 receptor-channels coupled with $\mathrm{Na}^{+}$influx in human $\mathrm{T}$ cells: role in T cell activation. J Neuroimmunol 1999;99:53-60.

$\checkmark 31$ Khan NA, Hichami A: Ionotrophic 5-hydroxytryptamine type 3 receptor activates the protein kinase C-dependent phospholipase d pathway in human T-cells. Biochem J 1999;344:199-204.

>32 Iken K, Cheng S, Fargin A, Goulet AC, Kouassi E: Serotonin upregulates mitogenstimulated B lymphocyte proliferation through 5-HT1A receptors. Cell Immunol 1995; 163:1-9.

$\checkmark 33$ Choquet D, Korn H: Dual effects of serotonin on a voltage-gated conductance in lymphocytes. Proc Natl Acad Sci USA 1988; 85:4557-4561.

-34 Serafeim A, Holder MJ, Grafton G, Chamba A, Drayson MT, Luong QT, Bunce CM, Gregory CD, Barnes NM, Gordon J: Selective serotonin reuptake inhibitors directly signal for apoptosis in biopsy-like Burkitt lymphoma cells. Blood 2003;101:3212-3219. 